\title{
塑性発熱を利用した自己昇温成形法の開発* (圧縮試験による荷重低減効果の検証)
}

\section{四宮 德章 ${ }^{* 1}$, 白川 信彦 ${ }^{* 2}$, 中本 貴之 ${ }^{* 2}$ \\ Development of New Forming Process Using Heat Generation by Plastic Deformation (Verification of Load Reduction Effect in Compression Test)}

\author{
Naruaki SHINOMIYA*1, Nobuhiko SHIRAKAWA and Takayuki NAKAMOTO \\ ${ }^{* 1}$ Technology Research Institute of Osaka Prefecture, Metals \& Machinery Department \\ Ayumino 2-7-1, Izumi-shi, Osaka, 594-1157 Japan
}

\begin{abstract}
Plastic deformation energy is transformed into heat in about 90 percent. If heat generation by plastic deformation of work metal is applied to its temperature rising, deformation resistance can be reduced. We propose a new cold stamping technology characterized by using a die which has low thermal conductivity to apply heat generation by plastic deformation to uniform temperature rising of work metal. Our aim in this study is to achieve ecological and technical advantages such as energy saving, high formability and high form accuracy. In this report, the effect of die materials and deformation rate on deformation load was examined by compression tests on TW340 and SUS304. The following results were obtained: 1) Deformation load on TW340 and SUS304 using $\mathrm{ZrO}_{2}$ for the die is lower than using SKD11 for the die to make efficient use of heat generation by plastic deformation. 2) Deformation rate has optimum value related to thermometric conductivity of work metal.
\end{abstract}

Key Words : Plastic Working, Heat Generation, Heat Transfer, Low Thermal Conductivity, Compression Test, Thermometric Conductivity

\section{1. 緒言}

プレス成形時の塑性変形仕事のうち $90 \%$ 程度は熱に変わると言われている ${ }^{(1)}$ (以下, 「塑性発熱」と称す). 理 論的に計算すると，変形抵抗 600MPa のチタン合金を相当塑性ひずみ 1.0 まで圧縮した場合 , 材料温度か約 $220^{\circ} \mathrm{C}$ 上昇するほど乥の発熱量は大きい，一般的に，材料の変形抵抗は温度上昇にともない低下することから，この塑 性発熱を利用して被加工材の温度上昇を達成できれば, 通常の冷間加工と比較して低荷重での成形が可能になる と考えられる.しかし現実には,成形中の被加工材は金型に接しているため,発生した熱の大半は金型に伝導し， 発生熱を成形に利用できるほと効果的な被加工材の温度上昇は望めない .

一方 , 温間加工では, 被加工材を炉で加熱したり金型をヒータで加熱して成形を行うことで, 冷間加工に比べ 成形荷重の低減や成形限界の向上を達成できるが，被加工材や金型を積極的に加熱するため，エネルギー消費は 大きい . 地球温暖化対策の観点から生産現場では省エネルギー化が一層求められており，エネルギ一消費を抑え た新しい成形方法の開発か望まれている.

本研究は, 金型材料に熱伝導率の低い材料を用いることで, 塑性発熱を被加工材の均一な昇温に活かし，省工 ネルギー効果が高く，成形性・寸法精度に優れた冷間加工法を確立することを目的とする．本報では，純チタン

(TW340) およびオーステナイト系ステンレス（SUS304）を対象に圧縮試験を行い, 圧縮荷重に及ぼす金型材種 および圧縮速度の影響について調べた。

* 原稿受付 2010 年 12 月 18 日

*1 正員，大阪府立産業技術総合研究所 機械金属部（广594-1157 大阪府和泉市あゆみ野 2-7-1）

*2 大阪府立産業技術総合研究所 機械金属部

E-mail: shinomiya@tri.pref.osaka.jp 


\section{2. 実験方法}

圧縮試験は，富士電波工機㑣)製の熱間加工再現試験装置 THERMECMASTOR-Z (FTZ-203A) を用いて行った . 図 1 に試験装置の概略を模式的に示す 被加工材はTW340およびSUS304とし, $\varphi$ 8mmの引抜き材から $\varphi 8 \times 12 \mathrm{~mm}$ $( \pm 0.05 \mathrm{~mm})$ の円柱試験片を切り出して試験に用いた . 金型形状は $\varphi 20 \times 10 \mathrm{~mm}$ の円柱状圧板とし , 金型材料に は , 一般的な冷間加工用金型材料である SKD11，熱伝導率の低い材料としてジルコニア $\left(\mathrm{ZrO}_{2}\right)$ とステライト， 熱伝導率の高い材料として超硬合金 (WC) を採用した.被加工材と金型材料の熱物性 (熱伝導率, 比熱, 密度, 温度伝導率) の参考值を光れぞれ表 1 と表 2 に示す.なお, 温度伝導率は, 熱伝導率を熱容量 (比熱と密度の積) で除したもので , 材料内の温度の伝わりやすさを示す物性である . 一方 , 試験片が金型に凝着する程度は金型材 種によって異なるため 試験片と各金型との摩擦条件を統一することを目的に試験片と金型の間に天然雲母板 $(\varphi$ $20 \times 0.2 \mathrm{~mm}$ ，熱伝導率 $0.7 \mathrm{~W} /(\mathrm{m} \cdot \mathrm{K})$ ，比熱 $206 \mathrm{~J} /(\mathrm{kg} \cdot \mathrm{K})$ ，密度 $\left.2,700 \mathrm{~kg} / \mathrm{m}^{3}\right)$ を敷いて試験を行った .また，試験片 が大気から熱的影響を受けないように，チャンバー内を真空 (1.5Pa 程度) にすることで対流の影響を小さくし， 試験片周辺をアルミ箔で覆うことで放射の影響を小さくした . 圧縮速度は , $0.1 \mathrm{~mm} / \mathrm{s}, 1.0 \mathrm{~mm} / \mathrm{s}, 10 \mathrm{~mm} / \mathrm{s}$ の三段階 に設定し, 試験片の温度上昇に及ぼす圧縮速度の影響を調べた . 圧縮中の試験片の温度は， R 型熱電対 (素線径 $0.2 \mathrm{~mm})$ を円柱試験片の側壁中央部表面に溶着して測定した。

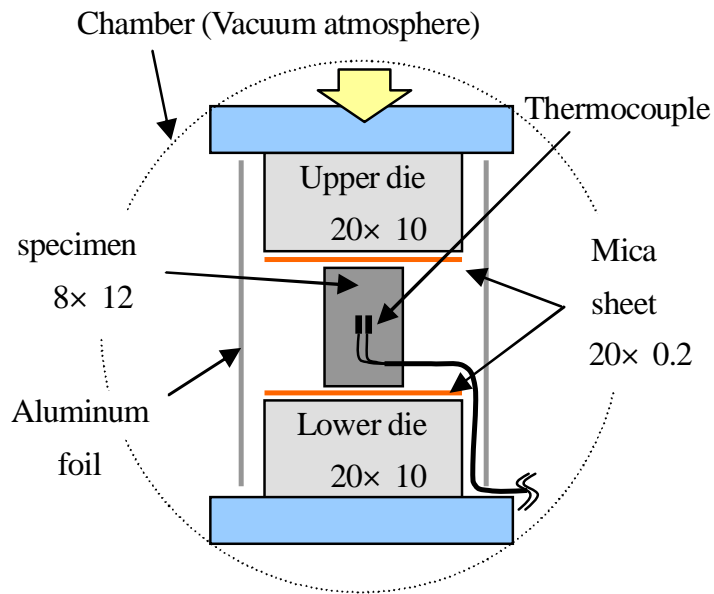

Table 1 Thermophysical properties of specimen

Fig.1 Schematic illustration of experimental apparatus for compression test

Table 2 Thermophysical properties of die

\begin{tabular}{c|c|c|c|c}
\hline \hline & $\begin{array}{c}\text { Thermal conductivity } \\
\lambda[\mathrm{W} /(\mathrm{m} \cdot \mathrm{K})]\end{array}$ & $\begin{array}{c}\text { Specific heat } \\
c_{p}[\mathrm{~J} /(\mathrm{kg} \cdot \mathrm{K})]\end{array}$ & $\begin{array}{c}\text { Density } \\
\rho\left[\mathrm{kg} / \mathrm{m}^{3}\right]\end{array}$ & $\begin{array}{c}\text { Thermometric conductivity } \\
\lambda /\left(c_{p} \cdot \rho\right) 10^{-6}\left[\mathrm{~m}^{2} / \mathrm{s}\right]\end{array}$ \\
\hline $\mathrm{SKD} 11$ & 29.3 & 460 & 7,800 & 8.2 \\
\hline $\mathrm{ZrO}_{2}$ & 3.0 & 500 & 6,000 & 1.0 \\
\hline Stellite & 15.0 & 381 & 8,500 & 4.6 \\
\hline $\mathrm{WC}$ & 41.9 & 250 & 13,900 & 12.1 \\
\hline
\end{tabular}

\section{3. 実験結果}

\section{$3 \cdot 1$ 試験片温度および圧縮荷重に及ぼす金型材種の影響}

図 2 は, TW340 を各種金型材により圧縮した場合の試験片温度あるいは圧縮荷重をストローク (圧縮量) て整 理したものである . なお，圧縮速度は $1.0 \mathrm{~mm} / \mathrm{s}$ に設定した . 同図(a)より，どの金型材を用いた場合においても， ストロークの増大にともなって , 試験片温度は上昇しており，圧縮にともなう塑性発熱が甡じていることがわか る.試験片温度の上昇の挙動を詳細に見ると，光の勾配は圧縮量が大きくなるにつれてゆるやかになるが，この 変化は, 圧縮の進行にともない試験片と金型の接触面積が大きくなり，試験片から金型への伝熱量が大きくなつ 


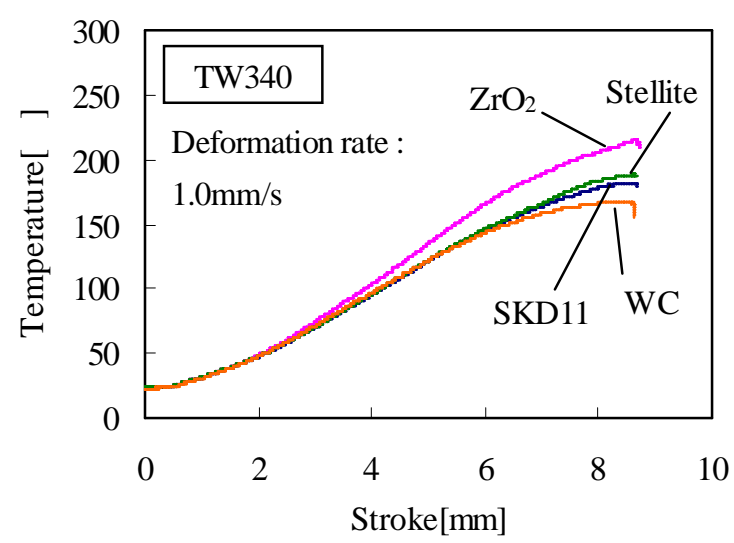

(a) Temperature

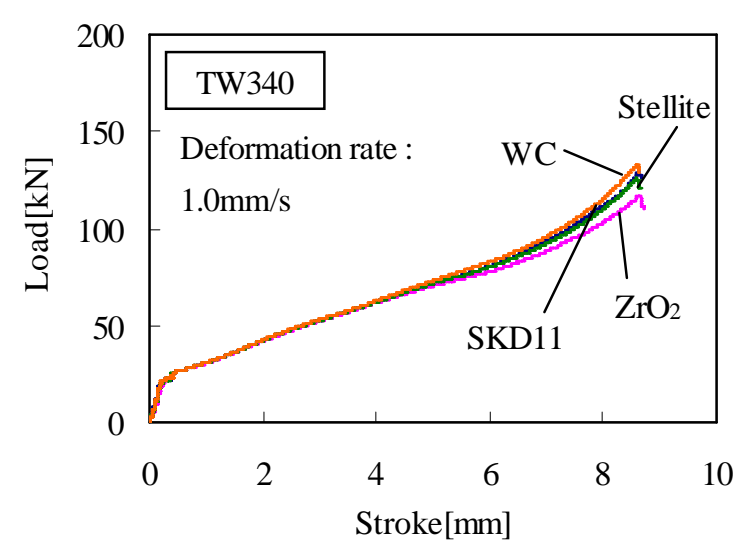

(b) Compressive load

Fig.2 Effect of die materials on compressive load and temperature (TW340)

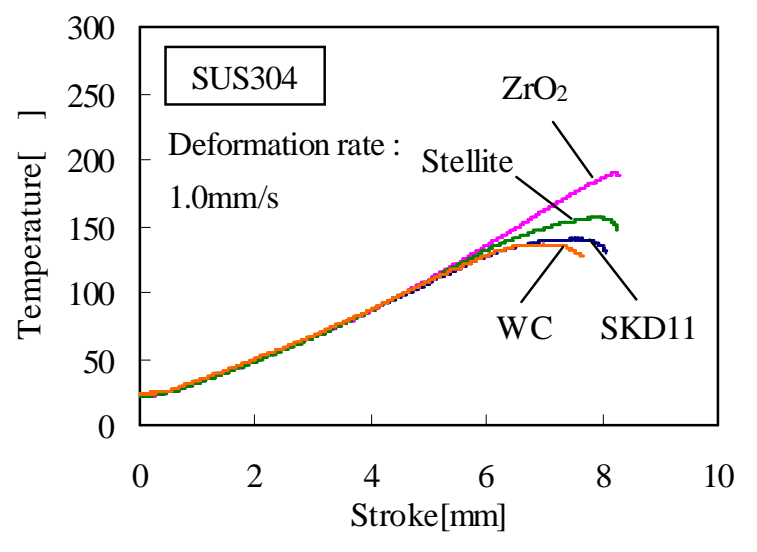

(a) Temperature

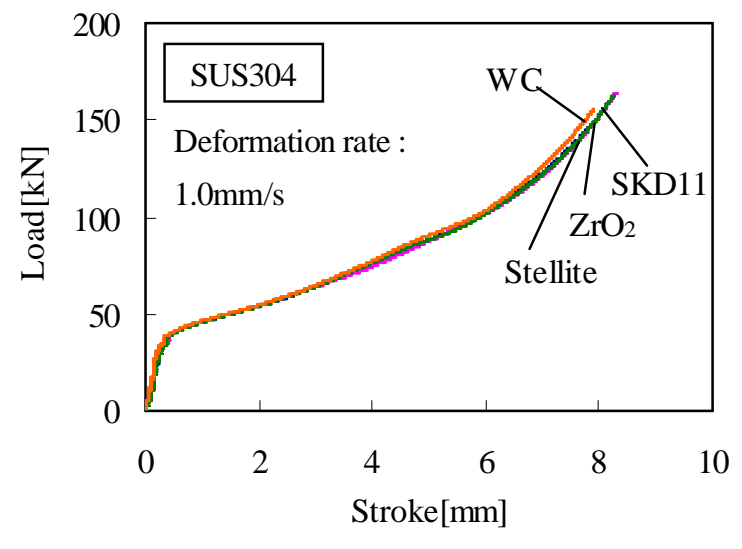

(b) Compressive load

Fig.3 Effect of die materials on compressive load and temperature (SUS304)

たために発生したものと考えられる．金型材の違いによる試験片温度の上昇について比較すると，ストローク $3.0 \mathrm{~mm}$ 付近から試験片温度に差が生じ始めており，特にジルコニア金型を用いた場合に試験片の温度上昇か湿著 であることがわかる . これは , 金型材に熱伝導率の低いジルコニアを用いることによって試験片から金型への伝 熱を抑制できることか理由のひとつと考えられる .一方，圧縮荷重については同図(b)より，ストロークの増大に ともない上昇しており，ストローク $5.0 \mathrm{~mm}$ 以降では金型材種によって差が生じることがわかる .これは, 試験片 温度の上昇に伴う変形抵抗の低減によるものと考えられ, 圧縮率 60\% (ストローク 7.2mm) では, WC 金型と比 較してジルコニア金型を用いた場合に圧縮荷重が 8.3\%低減した。

次に，SUS304 において試験片温度（あるいは圧縮荷重）とストロークの関係について，図 3 に示す．圧縮速 度については TW340 と同樣に $1.0 \mathrm{~mm} / \mathrm{s}$ とした . 同図(a)より，試験片温度は，ストローク $6.0 \mathrm{~mm}$ 付近までいずれ

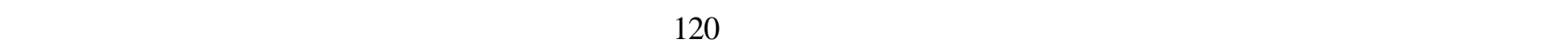
いが生じていることがわかる．TW340 とSUS304 の熱伝導率はほぼ同等であるにも関わらず，SUS304では金型 材の違いによる試験片の温度に差が生じ始めたストローク (TW340 ではストローク 3.0mm 付近 , SUS304 ではス トローク $6.0 \mathrm{~mm}$ 付近) が TW340 と比較して圧縮後半側に転じている .この要因のひとつとして , SUS304 の温度 伝導率か特に低いことが考えられる．つまり，SUS304では，ストローク $6.0 \mathrm{~mm}$ 付近までは，ひずみ量の大きい 試験片中央部での塑性発熱が，試験片の温度上昇として中央部から金型接触面付近へあまり伝わっていない，乥 のため, 試験片の金型接触面付近と金型表層の温度差が小さ，金型の熱伝導率にかかわらず金型への伝熱量は 小さくなった .また ,ストローク 6.0mm 以降では金型材の違いによる試験片の温度に差が生じたが 、同図(b)より， 圧縮荷重はほとんど差か認められなかった.SUS304 は室温から $100^{\circ} \mathrm{C}$ 付近の範囲て変形抵抗の急激な低減を示す (2)と言われており，100Cを超えた領域では変形抵抗力顕著に低下しないことが，この要因のひとつとして考えら 


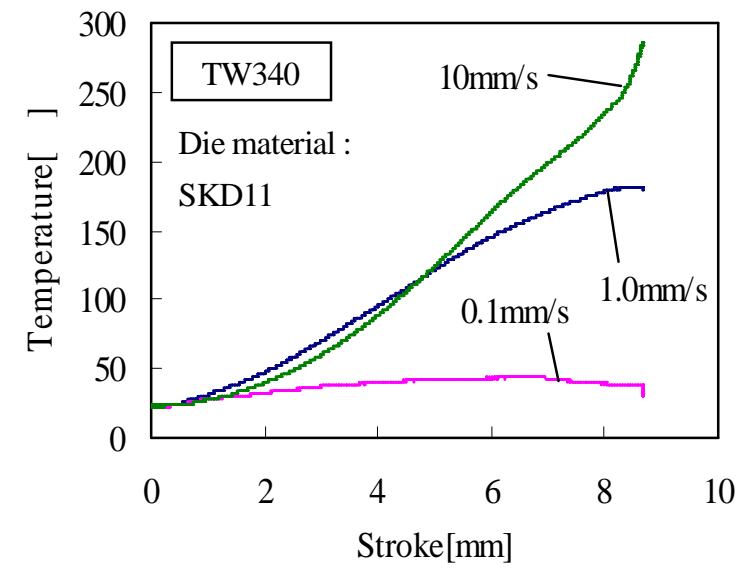

(a) Temperature

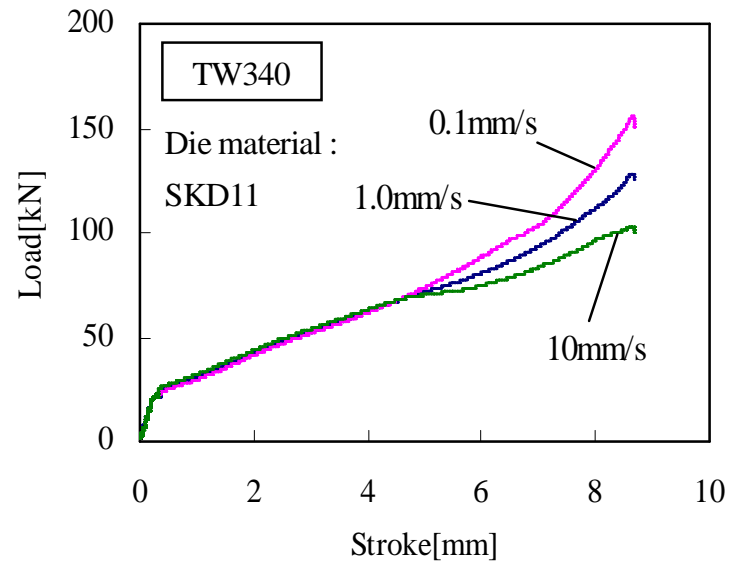

(b) Compressive load

Fig.4 Effect of deformation rate on compressive load and temperature (TW340)

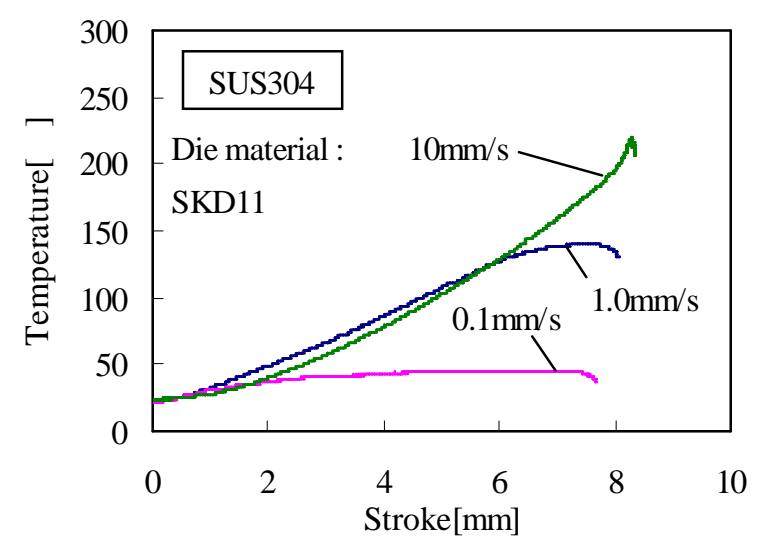

(a) Temperature

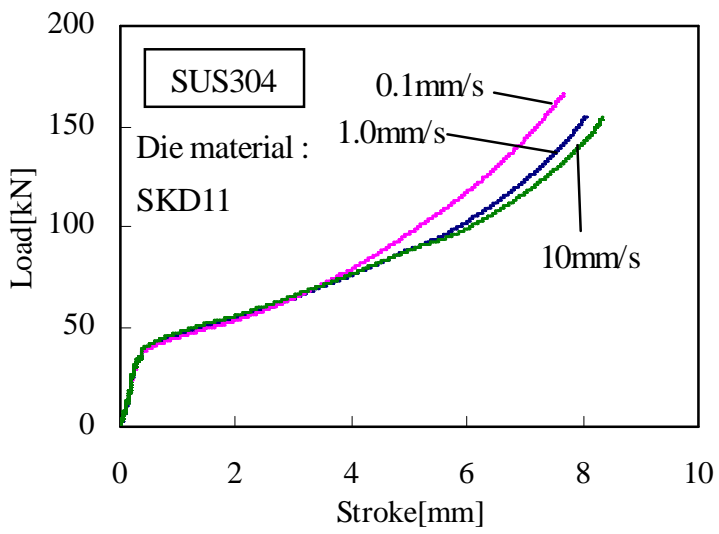

(b) Compressive load

Fig.5 Effect of deformation rate on compressive load and temperature (SUS304)

れる.

以上より，圧縮時の試験片の温度上昇は，金型材料の熱物性だけではなく，被加工材の温度伝導率に影響を受 け，乥れにともなう圧縮荷重の低減は，被加工材の変形抵抗の温度依存性に影響を受けると思われる．

\section{$3 \cdot 2$ 試験片温度および厈縮荷重に及ぼす厈縮速度の影響}

図 4 は，SKD11 の金型を用いて TW340 を圧縮した場合について, 試験片温度 (あるいは圧縮荷重) とストロ 一クの関係を示したものである.なお，圧縮速度は， $0.1 \mathrm{~mm} / \mathrm{s}, 1.0 \mathrm{~mm} / \mathrm{s}, 10 \mathrm{~mm} / \mathrm{s}$ に設定し，圧縮速度力試験片温 度および圧縮荷重に及ぼす影響を調べた。

図 4(a)より，圧縮速度が高いほどストロークの増大にともなう試験片温度の上昇が大きいことがわかる .これ は圧縮速度が高いほど金型へ熱が伝わる前に圧縮が進行するため, 試験片内部に熱力蓄えられたことか要因と考 えられる.この結果は変形抵抗の低減として現われ，同図(b)より明らかなように，ストロークが $5 \mathrm{~mm}$ よりき い場合において，圧縮荷重は速度が高いほど低くなった。

次に SUS304 において試験片温度および圧縮荷重とストロークの関係について図 5 に示す 金型材には ,TW340 と同樣にSKD11 を用いた . 同図(a)(b)より，SUS304 においても TW340 と同樣の傾向を示し，圧縮速度が高いほ どストロークの増大にともなう試験片温度の上昇が大きく，圧縮荷重は低かった．

\section{$3 \cdot 3$ 圧縮荷重に及ぼす金型材種および圧縮速度の影響}

各金型および各圧縮速度条件における 圧縮率 60\%(ストローク 7.2mm) 時の荷重を図 6 に示す 図より,TW340， SUS304 ともに, 高い圧縮速度では低い圧縮速度と比較して金型材種によらず荷重が低いことがわかる．また， 


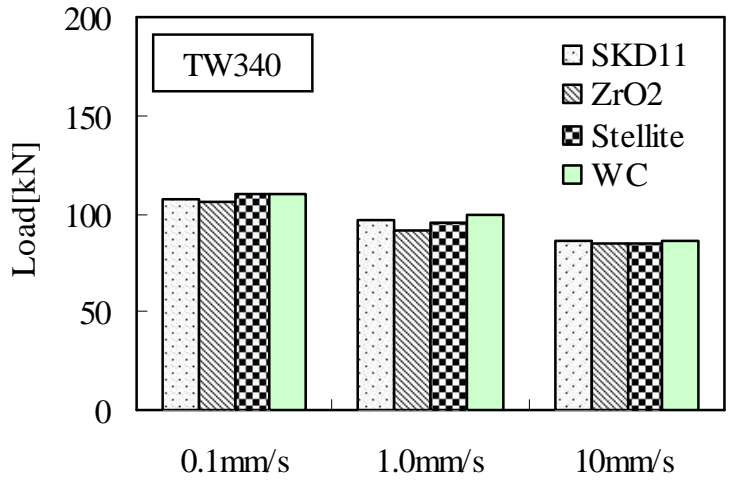

(a) Compressive load of TW340

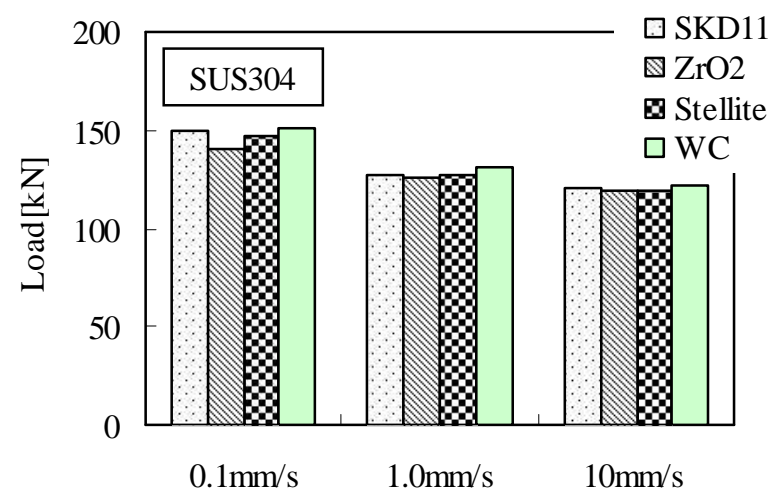

(b) Compressive load of SUS304

Fig.6 Variation of compressive load in each case (stroke 7.2mm)

低い圧縮速度では, 被加工材の材種にかかわらず熱伝導率の低い金型材を用いるほど荷重が低く，金型材にジル コニアを用いた場合に最も荷重は低い，金型材にジルコニアを用いた場合に，SKD11 と比較して，荷重が最も低 減した圧縮速度は，TW340 では $1.0 \mathrm{~mm} / \mathrm{s}, \mathrm{SUS} 304$ では $0.1 \mathrm{~mm} / \mathrm{s}$ であり，光れぞれ約 $5.8 \%$, 約 6.3\%荷重が低減し た。つまり，金型材にジルコニアを用いることによる荷重低減効果が大きい圧縮速度は，被加工材によって異な る.これは, 被加工材の変形抵抗の温度依存性に加えて, 被加工材の温度伝導率か影響を及ぼすと考えられ, 温 度伝導率が低い材料ほど荷重低減効果の大きい圧縮速度は低いと思われる。

以上のことより，TW340 および SUS304 では，圧縮速度を高めると金型材種によらず荷重が低減すること，お よび，熱伝導率の低い材料を金型に用いることで荷重を低減できることがわかった．しかし，高い成形速度では 成形中の被加工材料各部の温度差が大きい，光のことによる熱膨張・収縮が寸法精度を悪化させるといった報告 ${ }^{(3)}$ があることから, 荷重の低減と寸法精度の向上の両方を考慮すると, 熱伝導率の低い材料を金型に使用し, 荷 重低減効果の大きい成形速度を設定するとよいと思われる．

\section{4. 結 言}

金型材料に熱伝導率の低いジルコニアを用いることで, 塑性変形時の発熱を変形抵抗の低下に活用でき, 金型 材料にSKD11 を用いた場合と比較して圧縮荷重を低減できることがわかった .また，金型材種による荷重低減が 大きい圧縮速度は被加工材種により異なり，被加工材の変形抵抗の温度依存性だけではなく被加工材の温度伝導 率か影響を及ぼすことがわかった .

以上のことより，TW340 および SUS304において本成形法の適用の可能性を見出せたが，今後，実生産での適 用に向けて，被加工材と金型の接触面積が大きい後方押出し成形や深絞り成形，さらには多工程成形を対象に， 効果検証を進める予定である .

謝辞

最後に本研究の一部は 財団法人天田金属加工機械技術振興財団の平成 22 年度一般研究開発助成( AF-2010020) により行われた .ここに感謝の意を表します．

\section{文献}

（1）日本塑性加工学会鍛造分科会，わかりやすい鍛造加工，(2005)，p.31，日刊工業新聞社.

(2) 吉川育太郎, ステンレス鋼便覧，(1973)，p.174，日刊工業新聞社.

(3) 石黑太浩, 劉卜ウ, 吉田佳典, 湯川伸樹, 石川孝司 , サーボプレスを用いたスライドモーション制御による冷間後 方押出しの高精度化, 平成 22 年度塑性加工春季講演会 , (2010-5), pp.167-168. 